\title{
Essay \\ Domesticating the Undomesticated for Global Food and Nutritional Security: Four Steps
}

\author{
Ajeet Singh $₫$, Pradeep Kumar Dubey, Rajan Chaurasia $₫$, Rama Kant Dubey, \\ Krishna Kumar Pandey, Gopal Shankar Singh and Purushothaman Chirakkuzhyil Abhilash * \\ Institute of Environment \& Sustainable Development, Banaras Hindu University, Varanasi 221005, India \\ * Correspondence: pca.iesd@bhu.ac.in; Tel.: +91-94156-44280
}

Received: 8 July 2019; Accepted: 27 August 2019; Published: 28 August 2019

\begin{abstract}
Ensuring the food and nutritional demand of the ever-growing human population is a major sustainability challenge for humanity in this Anthropocene. The cultivation of climate resilient, adaptive and underutilized wild crops along with modern crop varieties is proposed as an innovative strategy for managing future agricultural production under the changing environmental conditions. Such underutilized and neglected wild crops have been recently projected by the Food and Agricultural Organization of the United Nations as 'future smart crops' as they are not only hardy, and resilient to changing climatic conditions, but also rich in nutrients. They need only minimal care and input, and therefore, they can be easily grown in degraded and nutrient-poor soil also. Moreover, they can be used for improving the adaptive traits of modern crops. The contribution of such neglected, and underutilized crops and their wild relatives to global food production is estimated to be around 115-120 billion US\$ per annum. Therefore, the exploitation of such lesser utilized and yet to be used wild crops is highly significant for climate resilient agriculture and thereby providing a good quality of life to one and all. Here we provide four steps, namely: (i) exploring the unexplored, (ii) refining the unrefined traits, (iii) cultivating the uncultivated, and (iv) popularizing the unpopular for the sustainable utilization of such wild crops as a resilient strategy for ensuring food and nutritional security and also urge the timely adoption of suitable frameworks for the large-scale exploitation of such wild species for achieving the UN Sustainable Development Goals.
\end{abstract}

Keywords: anthropocene; climate resilient; food and nutritional security; resource conservation; underutilized crops; Sustainable Development Goals

\section{Producing More with Less Resources: The Need of the Hour}

The sustainable utilization of our limited natural resources for maximizing the food production [1] within the planetary boundaries [2] is a serious challenge for attaining the United Nations Sustainable Development Goals (UN-SDGs), especially the first, second and third goals namely (i) no poverty, (ii) zero hunger and (iii) good health and wellbeing. Since the indiscriminate usage of a critical resource governing agricultural production, i.e., $\mathrm{N}$, has already crossed planetary boundaries [2], there is a growing concern regarding the cultivation of high-input demanding modern crop varieties under resource-poor conditions. Moreover, the quality and availability of two other inputs vital for agricultural production, i.e., water and land, are already in a thinning state [3,4]. The changing climatic condition is another impediment for food production as it negatively affects the quality and availability of the critical resources as well as the quality and quantity of the agricultural production itself [5]. Since we have to enhance the food production by $70 \%$ for meeting the demand of the growing population in 2050, the cultivation of resilient, nutritionally rich, and low-resource intensive crops are of paramount importance for human wellbeing and environmental sustainability [6]. In this context, [7,8] the domestication of undomesticated, wild and neglected crops and exploiting their natural traits to 
efficiently use critical natural resources such as N, P, water, and land offers huge promise in attaining future food security as they are bestowed with high nutritional value $[9,10]$ and adaptive traits [11]. Importantly, they need only minimal input and care so they can be easily cultivated in marginal and other nutrient-poor soil and even under changing climatic conditions [11]. Here we propose four important steps, i.e., (i) exploring the unexplored, (ii) refining the unrefined traits, (iii) cultivating the uncultivated, and (iv) popularizing the unpopular for the large-scale exploitation of such important but still underutilized and neglected crops for global food and nutritional security (Figure 1).

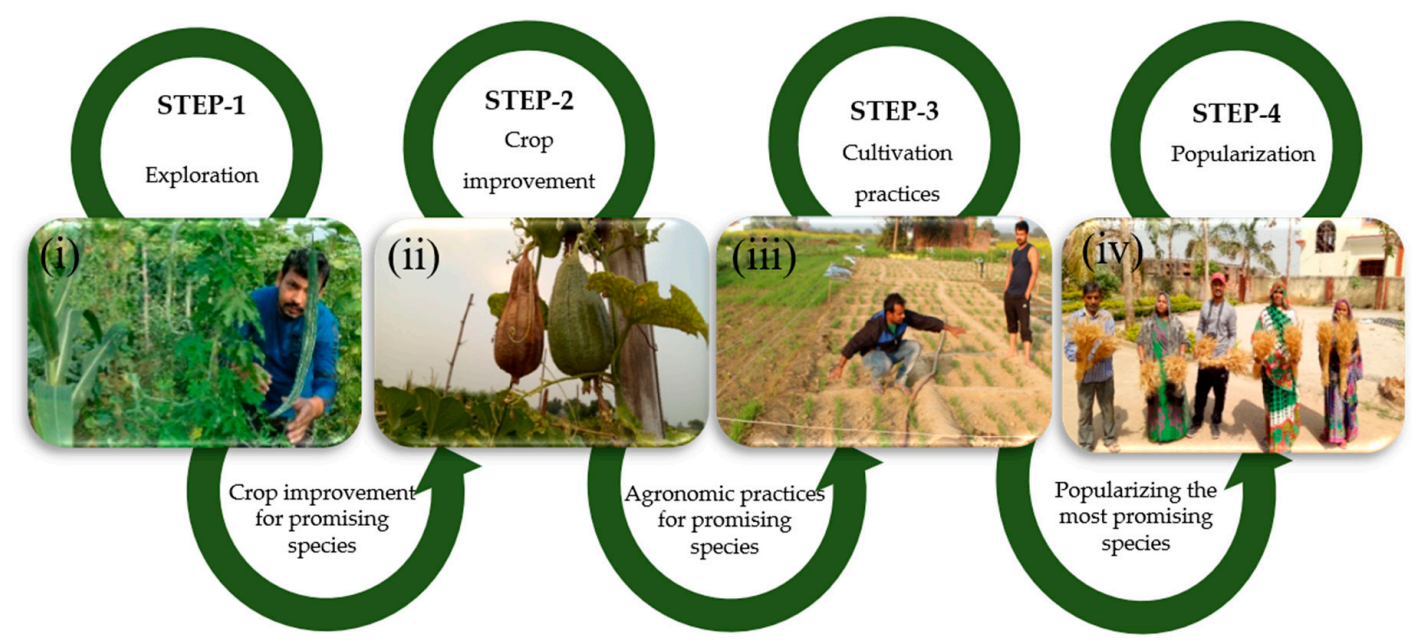

Figure 1. A casual loop diagram showing various steps involved in the sustainable utilization of wild and neglected crops for global food and nutritional security. (i) Step-1: exploration of various kind of wild and neglected crops; (ii) Step-2: improving the desirable traits in promising species by conventional as well as modern biotechnological approaches; (iii) Step-3: standardization and optimization of various agronomic practices for their large-scale exploitation and (iv) Step-4: the popularization of unpopular crops among farmers, policy makers, and other stakeholders.

\section{Exploring the Unexplored: First Step}

A list of nutritionally relevant, neglected and wild crops for global food security [10-14] is given in Table 1 . While it has been reported that about 5538 crops have been used for food by humans throughout the history, only 12 crops contribute the lion share of the current global food production [12,15]. Among this, three crops namely rice, wheat and maize account for $>50 \%$ the world's calories [15]. Though there are few estimates regarding the number of underutilized species (for example, Arora (2014) reported 992 species across the world), still a majority of them are unknown to various stakeholders. Therefore, the detailed exploration of such species from various agro-climatic regions of the world is important for identifying the promising species (Figure 2) like cereals/pseudo-cereals, roots and tubers, pulses, fruits and vegetables, nuts, seeds and spices etc. and their successful utilization in a dietary diversification program [9,15-17]. For this, a well-coordinated wild crop exploration program at various scales (i.e., national, regional, and global) are imperative. For example, Food and Agricultural Organization (FAO) has recently started an initiative to identify the Future Smart Food (FSF) crops on a regional basis and have identified 39 nutrition-sensitive and climate resilient crops from South and South East Asia as FSF [13] with the consultation of national experts from Bangladesh, Bhutan, Cambodia, India, Lao PDR, Myanmar, Nepal and Vietnam. While they proposed nine species of cereals/pseudo-cereals (buckwheat, tartary buckwheat, foxtail millet, porso millet, sorghum, amaranth, grain amaranth, quinoa, and specialty rice), six species of roots and tubers (taro, swamp taro, purple yam, fancy yam, elephants foot yam, and sweet potato), nine species of pulses (grasspea, fababean, cowpea, mungbean, blackbean, ricebean, lentil, horsebean, and soybean), 9 species of fruits and vegetables (drumstick, chayote, fenugreek, snake gourd, pumpkin, roselle, Indian gooseberry, jackfruit and wood apple), and five species of nuts, seeds and spices (linseed, walnut, Nepali butter tree, perilla and Nepali 
pepper) as FSFs for the South and South East Asia region [13] for further exploitation, there are many more neglected and wild species to be included and projected as FSFs (Figure 3A,B). For an instance, a detailed survey conducted by authors during the last few years in India (Figure 3) has revealed that there are many potential FSF such as finger millet, kodo millet, little millet (cereals/pseudo-cereals), air potato, turnip, kohlrabi, kudzu (roots and tubers), winged bean, sword bean, pigeon pea, chick pea (pulses), spine gourd, clove bean, phalsa, custard apple, kadamba, chenopodium, brown mustard, water spinach, jujube, ground cherry (fruits and vegetables) [10] etc. to be included in the regional list and thereby encouraged to be exploited them for future food security (for more such species, please see Figure $3 \mathrm{~A}$ and Table 1). The cultivation of such species are not only important for global food security but also for attaining many other UN-SDGs (Figure 3B).
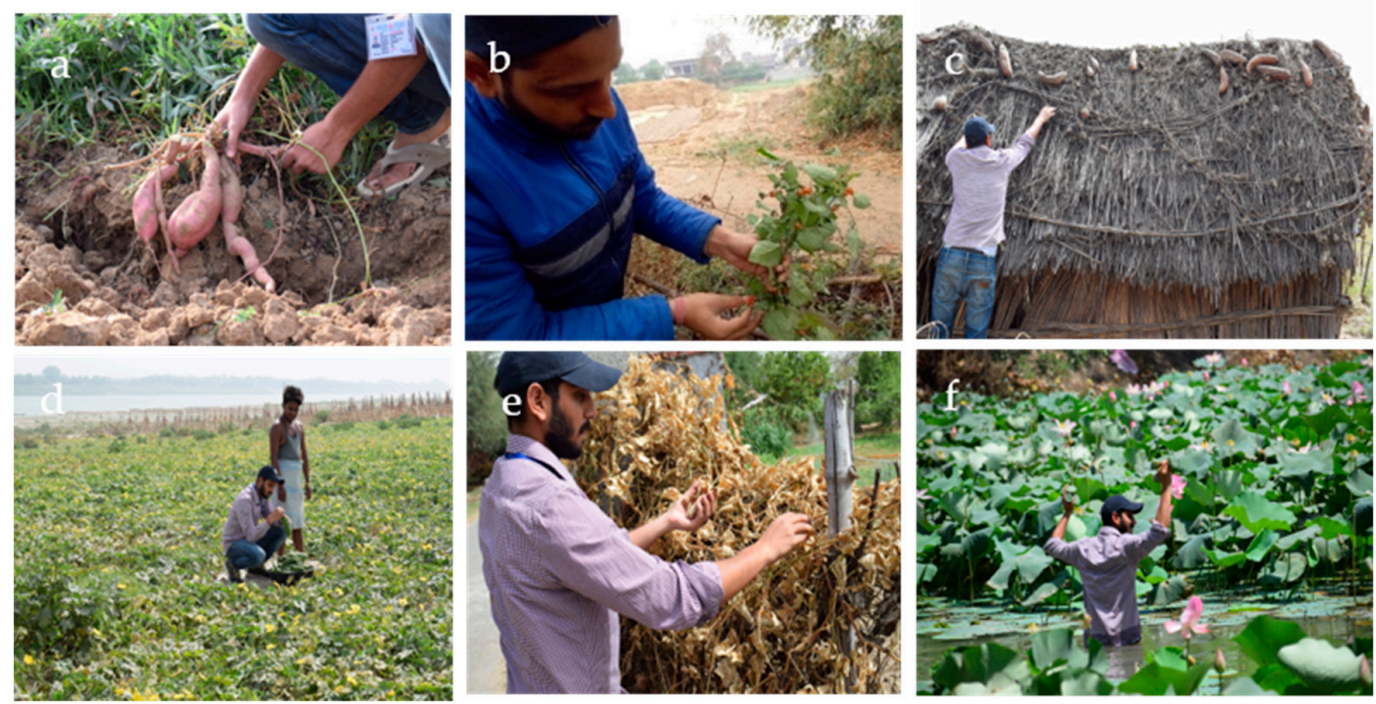

Figure 2. Exploration and germplasm collection of wild crops from diverse habitat ((a-e) collection from farmer's field, backyard and kitchen garden; (f) pond) is essential for identifying most promising species.
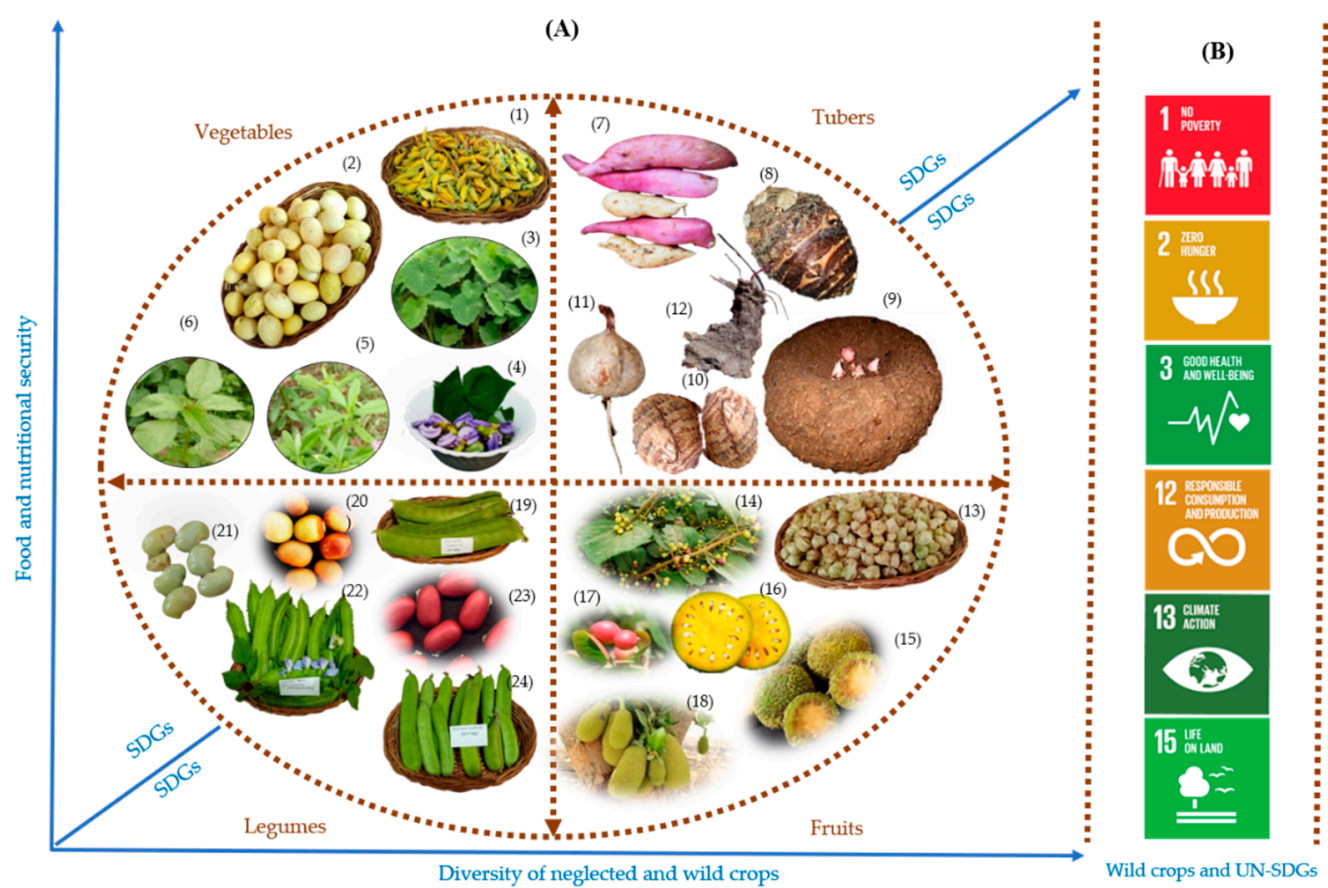

Figure 3. Schematic representation of the inter-relationship between diversity of wild and neglected crops, food and nutritional security and UN-SDGs. (A) food and nutritional security increases with the 
large-scale exploitation of neglected and wild crops. Circle shows various neglected wild species: (1) Indian hemp (Crotalaria juncea); (2) Tarali (Melothria heterophylla); (3) Taro (Colocasia esculenta); (4) Flower and leaves of Winged bean (Psophocarpus tetragonolobus); (5) Water leaf (Talinum fruticosum); (6) Indian jute (Corchorus olitorius); (7) Wild sweet potato (Ipomoea batatas); (8) Elephant's ear (Colocasia gigantea); (9) Elephant foot yam (Amorphophallus paeoniifolius); (10) Taro (Colocasia esculenta); (11) Indian Kudzu (Pueraria tuberosa); (12) Tuber of purple yam (Dioscorea alata);(13) Winter cherry (Physalis angulata); (14) Phalsa (Grewia asiatica); (15) Bur flower tree (Neolamarckia cadamba); (16) Wood apple (Aegle marmelos); (17) Karanda (Carissa carandas); (18) Jackfruit (Artocarpus heterophyllus); (19) Pods of large sword bean (Canavalia gladiata); (20) Seeds of winged bean (Psophocarpus tetragonolobus); (21) Seeds of vegetable hummingbird (Sesbania grandiflora); (22) Pods of winged bean (Psophocarpus tetragonolobus); (23) Seeds of large sword bean (Canavalia gladiata); and (24) Sword bean (Canavalia virosa) (B) Sustainable utilization of wild and neglected crops are essential for attaining UN-SDGs.

Table 1. An indicative list of promising neglected and underutilized species such as roots and tubers, cereals and pseudo-cereals, fruits and nuts, vegetables, legumes, spices, condiments, and food-dye agents for global food and nutritional security [10-14].

\begin{tabular}{|c|c|c|}
\hline SL No. & Common Name & Scientific Name \\
\hline \multicolumn{3}{|c|}{ (A) Roots and tubers } \\
\hline 1 & Yams & Dioscorea spp. \\
\hline 2 & Yacon & Smallanthus sonchifolius \\
\hline 3 & Ulluco & Ullucus tuberosus \\
\hline 4 & Taro & Colocasia esculenta \\
\hline 5 & Arracacha & Arracacia xanthorriza \\
\hline 6 & American yam bean & Pachyrhizus spp \\
\hline 7 & Maca & Lepidium meyenii \\
\hline 8 & Oca & Oxalis tuberosa \\
\hline 9 & Parsnip & Pastinaca sativa \\
\hline 10 & Cocoyam & Xanthosoma sagittifolium \\
\hline 11 & Elephant foot yam & Amorphophallus paeoniifolius \\
\hline 12 & Kohlrabi & Brassica oleracea var. gongylodes $L$ \\
\hline 13 & Wild turnip & Brassica rapa var. rapa \\
\hline 14 & Eddoe & Colocasia antiquorum \\
\hline 15 & Sweet potato & Ipomea batatas \\
\hline 16 & Indian lotus & Nelumbo nucifera Gaertn. \\
\hline 17 & Country potato & Plectranthus rotundifolius \\
\hline 18 & Wild cassava & Manihot spp. \\
\hline 19 & Indian Kudzu & Pueraria tuberosa \\
\hline 20 & Edible Chlorophytum & Chlorophytum tuberosum \\
\hline 21 & Asparagus & Asparagus racemosus \\
\hline \multicolumn{3}{|c|}{ (B) Cereals and pseudo-cereals } \\
\hline 22 & Einkorn & Triticum monococcum \\
\hline 23 & Emmer & T. dicoccon \\
\hline 24 & Spelt & T. spelta \\
\hline 25 & Tef & Eragrostis tef \\
\hline
\end{tabular}


Table 1. Cont.

\begin{tabular}{|c|c|c|}
\hline SL No. & Common Name & Scientific Name \\
\hline 26 & Fonio & Digitaria exilis \\
\hline 27 & Cañihua & Chenopodium pallidicaule \\
\hline 28 & Finger millet & Eleusine coracana \\
\hline 29 & Kodo millet & Paspalum scrobiculatum \\
\hline 30 & Foxtail millet & Setaria italic \\
\hline 31 & Little millet & Panicum sumatrense \\
\hline 32 & Proso millet & Panicum miliaceum \\
\hline 33 & Amaranth & Amaranthus caudatus \\
\hline 34 & Buckwheat & Fagopyrum spp. \\
\hline 35 & Job's tears & Coix lacryma-jobi \\
\hline 36 & Red amaranth & Amaranthus cruentus L \\
\hline 37 & Pearl Millet & Pennisetum glaucum (L.) R.Br. \\
\hline \multicolumn{3}{|c|}{ (C) Fruits and nuts } \\
\hline 38 & Maya nut & Brosimum alicastrum \\
\hline 39 & Breadfruit & Artocarpus altilis \\
\hline 40 & Jackfruit & Artocarpus heterophyllus \\
\hline 41 & Wild jackfruit & Artocarpus hirsutus \\
\hline 42 & Fox nut & Euryale ferox \\
\hline 43 & Baobab & Adansonia digitate \\
\hline 44 & Jujube & Ziziphus mauritiana \\
\hline 45 & Cherimoya & Annona cherimola \\
\hline 46 & Cape gooseberry & Physalis peruviana \\
\hline 47 & Naranjilla & Solanum quitoense \\
\hline 48 & Pomegranate & Punica granatum \\
\hline 49 & Noni & Morinda citrifolia \\
\hline 50 & Marula & Sclerocarya birrea \\
\hline 51 & Tamarind & Tamarindus indica \\
\hline 52 & Annona & Annona spp. \\
\hline 53 & Safou & Dacryodes edulis \\
\hline 54 & Mangosteen & Garcinia mangostana \\
\hline 55 & Salak & Salacca spp. \\
\hline 56 & Nipa palm & Nypa fruticans \\
\hline 57 & Monkey orange & Strychnos cocculoides \\
\hline 58 & Duku & Lansium domesticum \\
\hline 59 & Boscia & Boscia spp. \\
\hline 60 & Carissa & Carissa edulis \\
\hline 61 & Coccinia & Coccinia trilobata \\
\hline 62 & Acacia & Acacia toritilis \\
\hline 63 & Kei apple & Dovyalis caffra \\
\hline 64 & Tree grapes & Lamnea spp. \\
\hline
\end{tabular}


Table 1. Cont.

\begin{tabular}{|c|c|c|}
\hline SL No. & Common Name & Scientific Name \\
\hline 65 & Medlars & Vanguera spp. \\
\hline 66 & Pitanga & Eugenia uniflora \\
\hline 67 & Malabar chestnut & Pachira aquatica \\
\hline 68 & Camu camu & Myrciaria dubia \\
\hline 69 & Dragon fruit & Hylocereus spp. \\
\hline 70 & Brazil nut & Bertholletia excels \\
\hline 71 & Egg nut & Couepia longipendula \\
\hline 72 & Quince & Cydonia oblonga \\
\hline 73 & Yara Yara & Duguetia lepidota \\
\hline 74 & Araza & Eugenia stipitate \\
\hline 75 & Lúcuma & Lucuma obovate \\
\hline 76 & Miracle fruit & Synsepalum dulcificum \\
\hline 77 & Water chestnut & Trapa natans \\
\hline 78 & Indian bael & Aegle marmelos \\
\hline 79 & Chilean wineberry & Aristotelia chilensis (Molina) \\
\hline 80 & Lakoocha & Artocarpus lacucha \\
\hline 81 & Karanda & Carissa carandas \\
\hline 82 & Assyrian plum & Cordia myxa \\
\hline 83 & Cluster Fig & Ficus racemosa \\
\hline 84 & Phalsa & Grewia asiatica \\
\hline 85 & Wood-apple & Limonia acidissima $L$. \\
\hline 86 & Mulberries & Morus alba \\
\hline 87 & Burflower-tree & Neolamarckia cadamba \\
\hline 88 & Indian Gooseberry & Phyllanthus emblica \\
\hline 89 & Angular winter cherry & Physalis angulata \\
\hline 90 & Manila tamarind & Pithecellobium dulce (Roxb.) Benth. \\
\hline 91 & Black nightshade & Solanum nigrum L. \\
\hline 92 & Indian almond & Terminalia catappa L. \\
\hline 93 & Jujube & Ziziphus jujube \\
\hline 94 & Mahua & Madhuca longifolia \\
\hline 95 & Hog Plum & Spondias dulcis \\
\hline 96 & Starfruit & Averrhoa carambola \\
\hline 97 & Bilimbi & Averrhoa bilimbi \\
\hline 98 & Indian coffee plum & Flacourtia jangomas \\
\hline 99 & Common guava & Psidium guajava \\
\hline 100 & Soursop & Annona muricata \\
\hline 101 & Spring Asparagus & Asparagus officinalis \\
\hline 102 & Wild pear & Pyrus communis \\
\hline 103 & Hill lemon & Citrus psedolimon \\
\hline
\end{tabular}


Table 1. Cont.

\begin{tabular}{|c|c|c|}
\hline SL No. & Common Name & Scientific Name \\
\hline \multicolumn{3}{|c|}{ (D) Vegetables } \\
\hline 104 & Moringa & Moringa oleifera \\
\hline 105 & African eggplant & Solanum aethiopicum \\
\hline 106 & Thorny amaranth & Amaranthus spinosa \\
\hline 107 & Wild amaranth & Amranthus viridis \\
\hline 108 & Brassica & Brassica rapa varieties \\
\hline 109 & Locust bean & Parkia biglobosa \\
\hline 110 & Chayote & Sechium edule \\
\hline 111 & Chrysanthemum & Chrysanthemum oronarium \\
\hline 112 & Bitter gourd & Momordica charantia \\
\hline 113 & Angle gourd & Luffa acutangular \\
\hline 114 & Snake gourd & $\begin{array}{l}\text { Thrichosantes cucumerina var. } \\
\text { anguina }\end{array}$ \\
\hline 115 & Indian spinach & Basella rubra, Basella alba \\
\hline 116 & Spider plant & Cleome gynandra \\
\hline 117 & Jute & Corchorus olitorius \\
\hline 118 & Black nightshade & Solanum nigrum \\
\hline 119 & Ivy gourd & Coccinia grandis \\
\hline 120 & Gourd & Lagenaria siceraria \\
\hline 121 & Celosia & Celosia argentea \\
\hline 122 & Dika & Irvingia spp. \\
\hline 123 & Egusi & Citrullus lanatus \\
\hline 124 & Marama & Tylosema esculentum \\
\hline 125 & Shea butter & Vitellaria paradoxa \\
\hline 126 & Giant swamp taro & Cyrtosperma merkusii \\
\hline 127 & Akoub & Gundelia tournefortii \\
\hline 128 & Crambe & Crambe spp. \\
\hline 129 & Cardoon & Cynara cardunculus \\
\hline 130 & Eru & Gnetum africanum \\
\hline 131 & Purslane & Portulaca oleracea \\
\hline 132 & Golden thistle & Scolymus hispanicus \\
\hline 133 & Bitter leaf & Vernonia amygdalina \\
\hline 134 & Cabbage Leaf Mustard & Brassica juncea var. rugosa \\
\hline 135 & Pigweed & Chenopodium album \\
\hline 136 & Asian spiderflower & Cleome viscosa \\
\hline 137 & False Amaranth & Digera muricate (L.) Mart. \\
\hline 138 & Water spinach & Ipomoea aquatica \\
\hline 139 & Thumbai & Leucas aspera (Willd.) Linn \\
\hline 140 & Sweet neem & Murraya koenigii \\
\hline 141 & Sickle Senna & Senna tora \\
\hline
\end{tabular}


Table 1. Cont.

\begin{tabular}{|c|c|c|}
\hline SL No. & Common Name & Scientific Name \\
\hline 142 & Waterleaf & Talinum fruticosum (L.) Juss \\
\hline 143 & Fenugreek & Trigonella foenum graecum \\
\hline 144 & Spiny gourd & Momordica dioica Roxb. Ex Willd. \\
\hline 145 & Pointed gourd & Trichosanthes dioica Roxb. \\
\hline 146 & Sunn hemp & Crotalaria juncea L. \\
\hline 147 & Khejri Tree & Prosopis cineraria \\
\hline 148 & Sweet leaf & Sauropus androgynus \\
\hline 149 & Water spinach & Ipomea aquatica \\
\hline 150 & Tarali & Melothria heterophylla \\
\hline 151 & Kuda & Holarrhena pubescens \\
\hline 152 & Korla & Bauhinia malabarica \\
\hline 153 & Kawla & Smithia hirsuta \\
\hline 154 & Dragon stalk yam & Amorphophallus commutatus \\
\hline 155 & Bamboo & Dendrocalamus strictus \\
\hline 156 & Wild senna & Senna tora \\
\hline 157 & Dinda & Leea indica \\
\hline 158 & Bharangi & Rotheca serrata \\
\hline 159 & Edible fern & Diplazium esculentum \\
\hline \multicolumn{3}{|c|}{ (E) Legumes } \\
\hline 160 & Mungbean & Vigna radiata \\
\hline 161 & Adzuki bean & V. angularis \\
\hline 162 & Ricebean & V. umbellata \\
\hline 163 & Lupin & Lupinus mutabilis \\
\hline 164 & Bambara groundnut & Vigna subterranean \\
\hline 165 & Jack bean & Canavalia ensiformis \\
\hline 166 & Grasspea & Lathyrus sativus \\
\hline 167 & Lablab & Lablab purpureus \\
\hline 168 & Pigeon pea & Cajanus cajan \\
\hline 169 & African yam bean & Sphenostylis stenocarpa \\
\hline 170 & Kersting's groundnut & Macrotyloma geocarpum \\
\hline 171 & Sword bean & Canavalia gladiata \\
\hline 172 & Jack bean & Canavalia virosa \\
\hline 173 & Winged bean & Psophocarpus tetragonolobus \\
\hline 174 & Cluster bean & Cyamopsis tetragonoloba (L.) Taub \\
\hline 175 & Agati & Sesbania grandiflora (L.) Pers. \\
\hline 176 & Broad bean & Vicia faba \\
\hline 177 & Chickpea & Cicer arietinum \\
\hline 178 & Peanut & Arachis hypogea \\
\hline 179 & Black gram & Vigna mungo \\
\hline 180 & Black lentil & Lens culinaris \\
\hline
\end{tabular}


Table 1. Cont.

\begin{tabular}{ccc}
\hline SL No. & Common Name & Scientific Name \\
\hline 181 & (F) Spices, condiments, food-dye agents \\
\hline 182 & Makoni & Fadogia ancylantha \\
\hline 183 & Annatto & Bixa orellana \\
\hline 184 & Mustard seed & Brassica juncea \\
\hline 185 & Fenugreek & Trigonella foenumgraecum \\
\hline 186 & Pandan & Pandanus amaryllifolius \\
\hline 187 & Polygonum & Poligonum odoratum \\
\hline 188 & Antidesma & Antidesma venosum \\
\hline 189 & Uer & Lippia carviodora \\
\hline 190 & Rocket & Diplotaxis spp \\
\hline 191 & Caper & Capparis spinosa \\
\hline 192 & Monkey cola & Cola lateritia \\
\hline 193 & Sea buckthorn & Hippophae rhamnoides \\
\hline 194 & Nigella & Nigella sativa \\
\hline 195 & Culantro & Eryngium foetidum \\
\hline 196 & Coriander & Coriandrum sativum \\
\hline & Wild chilies & Capsicum spp. \\
\hline
\end{tabular}

The application of biotechnological advances for exploring crop diversity like genotyping by sequencing, genotyping arrays, and pangenomics approaches [18] is another important strategy for assessing genetic diversity. Crop genome sequencing can provide insight into genetic variation through the re-sequencing [19]. Jiao et al. (2012) re-sequenced 278 elite maize lines (USA and Chinese maize lines) and identified $>27$ million single-nucleotide polymorphisms (SNPs). Similarly, the 3000-rice genome project resulted in the identification of $>18.9$ million SNPs $[20,21]$ and the methylation-sensitive digestion of genomic DNA coupled with next- generation sequencing in wheat resulted in 23,500 SNPs [22]. Furthermore, whole-genome re-sequencing was also done for barley [23], soybean [24], and lupin [25].

However, whole-genome sequencing is yet to be done in many promising but neglected crops and there are many wild species yet to be explored for their food and nutritional significance. For example, exploring the diversity in root and tuber crops are essential for the food security, especially in tropical regions as they are nutritionally rich and widely found in tropical regions [26]. Vigna is another important legume genus having more than a 100 species of high nutritional value for human and animal consumption [27]. Among this, only 10 species have been domesticated so far and the potential of the rest of the remaining 90 species is yet to be explored. Prickly pear (Opuntia spp.) is another valuable fruit crop for the semi-arid regions [28]. Similarly, Indian spinach or Malabar spinach (Basella species), is a resilient, nutritionally significant, perennial leafy vegetable native to tropical region [11]. However, as in the case of many other tropical leafy vegetables such as wild amaranth [10], water spinach, and waterleaf etc., Basella species are yet to be exploited for the dietary diversification program and food security [11]. Therefore, the large-scale exploration of underutilized and neglected crop species from various agro-climatic regions of the world, with the active involvements of the Consultative Group on International Agricultural Research (CGIAR) institutions, Crop Trust, local and national institutions, and with the financial support from Food and Agricultural Organization of the United Nations (UN-FAO), corporate bodies (through corporate social responsibility), Non-Governmental 
Organizations (NGOs), and also from concerned national governments, are imperative for exploring the most promising species as well as identifying the current diversity of such wild species.

Applications of geoinformatics tools such as remote sensing and geographical information system (RS \& GISs) can be used for mapping the distribution of neglected and wild crops [29] in various agro-climatic regions of the world, as well as modelling their habitat suitability for identifying the most suitable areas for large-scale cultivation $[17,30]$. Apart from the large-scale exploration of neglected and underutilized species from diverse habitats and agroecological zones of the world, the conservation of promising species is also equally important for facilitating their future utilization $[6,14]$. The exploitation of indigenous and local knowledge (ILK) along with the successful incorporation of the biocultural practices of the local people are very much essential for applying the traditional mode of conservation (Figure 4), whereas the exploitation of modern techniques for germplasm storage is also essential for maintaining such vital resources for the future use $[13,14]$. Creating community gene banks at farmer's fields is an excellent strategy for the long-term conservation of such underutilized species (Figure 5).

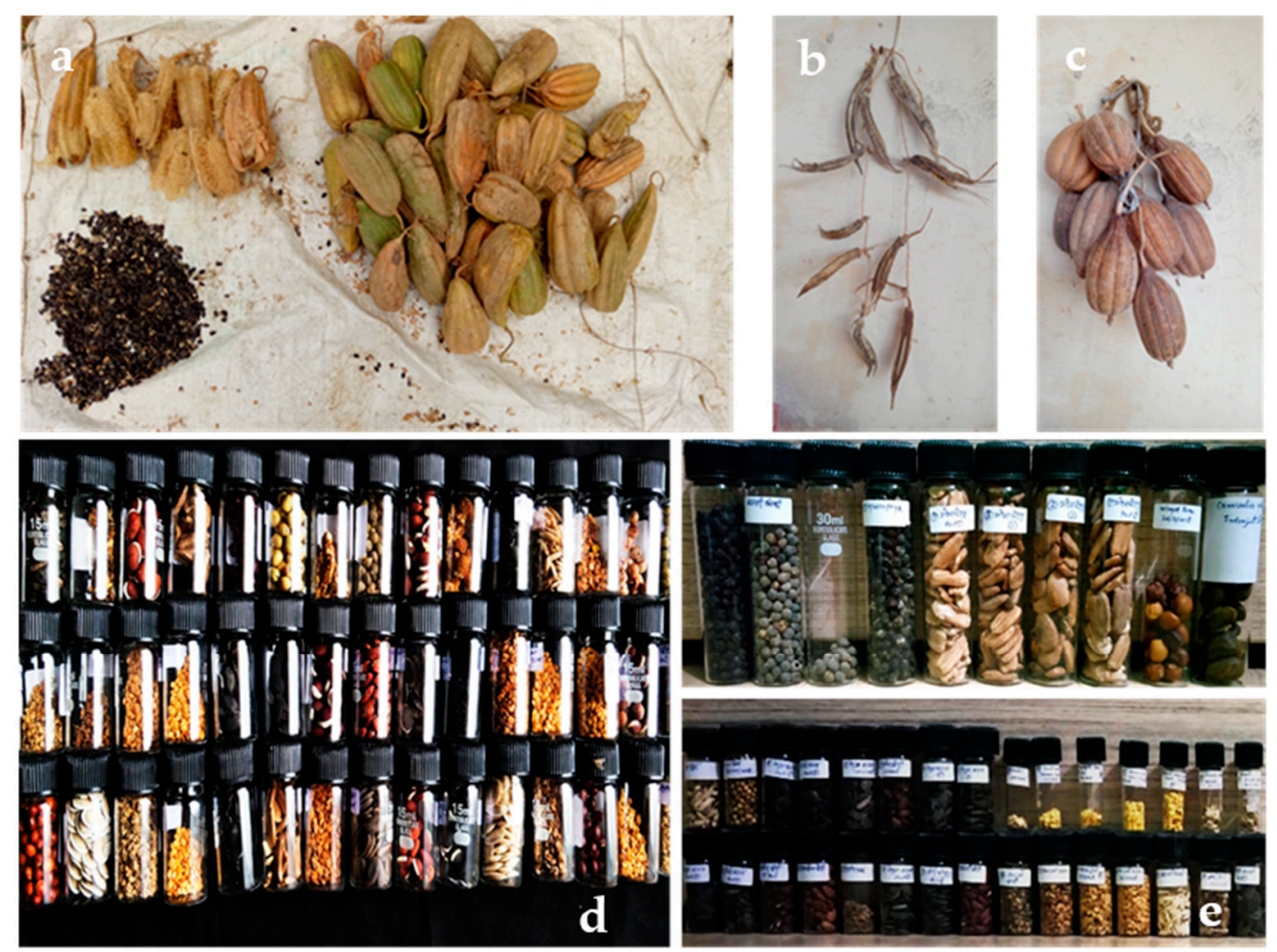

Figure 4. Apart from the exploration of wild and neglected crops, conservation of the germplasms of most promising species are also equally important for their sustainable utilization. For this, a blend of traditional $(\mathbf{a}-\mathbf{c})$ as well as modern $(\mathbf{d}, \mathbf{e})$ germplasm storage technologies should be adopted. 


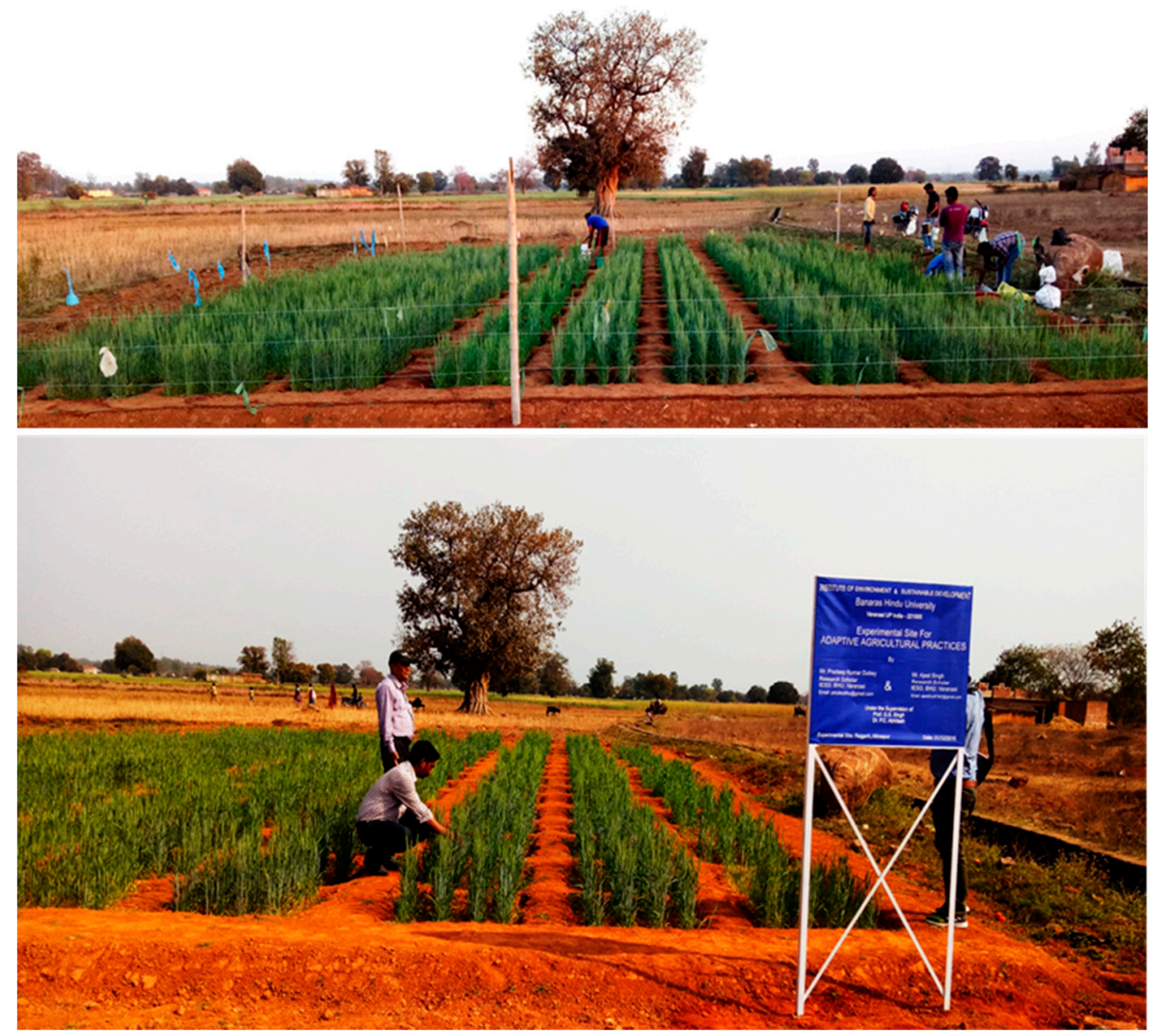

Figure 5. Field gene bank for conservation of neglected and underutilized crops. Maintaining germplasms of promising species at farmer's field itself is a promising strategy for conservation. Figures shows the cultivation of wheat in the farmer's field of Rajgarh, Mirzapur district, UP, India.

\section{Refining the Unrefined Traits: Second Step}

While modern agriculture aiming for higher productions prefers new cultivars that are developed through selection and fixation of favorable alleles providing most desirable traits, unscientific practices coupled with due negligence results in loss of wild or traditional crops and crop varieties and thereby causing genetic erosion and decline in landraces and ecotypes [31]. Therefore, once the promising wild and neglected species have been identified, developing a suitable crop improvement program for traiting or featuring desirable traits is another major strategy. Though most of the wild species are endowed with many positive traits such as stress tolerance (drought, flood, salinity, heat, pest and diseases, etc.) and able to grow even in resource-poor conditions $[5,7,9]$, these attributes can be further refined by crop improvement by using next generation sequencing (NGS) for genomic selection [32], the identification of candidate loci using quantitative trait locus (QTL) analyses, targeted gene replacement using zinc-finger nucleases and transcription activator-like effector nucleases and also by using clustered regularly interspaced short palindromic repeats (CRISPR/Cas system) etc. [18,33-36].

The application of genomic technologies [37] was found to increase the productivity of several orphan crops such as cassava, sweet potato, coconut, sorghum, yam, groundnut, common bean, chickpea, cowpea, cacao etc. [18], especially, exploring plant microRNAs (miRNAs) for developing climate resilient crops [38]. Khan et al. (2019) proposed the application of CRISPR-Cas9 for engineering the domestication traits in wild tomato for higher nutritive value and better adaptation to multiple stresses [39]. Pigeon pea (Cajanus cajan) is another versatile, stress tolerant and nutritious grain legume for enhancing the sustainability of dry tropical and sub-tropical system [40] and therefore, the crop 
breeding programs in pigeon pea has resulted in enhancing its tolerance to heat, cold, drought and waterlogging [40]. Muthamilarasan et al. (2016) explored the application of omics technologies for exploring suitable millet models for developing nutrient rich graminaceous crops [41]. De novo sequencing and comparative leaf transcriptome analysis of underutilized winged bean (Psophocarpus tetragonolobus (L.) DC) has been done by Singh et al. (2017) for removing the anti-nutritional factors in winged bean like condensed tannin (CT) and proanthocyanidin (PA) [42]. Such transcriptomic insights can be used for removing the antinutritional factors (high tannin and lignin content) in sword bean also. Lemmon et al. (2018) enhanced the domestication traits in an orphan crop of Solanaceae (groundcherry) by gene editing [36]. While biotechnological advances have revolutionized the crop breeding domain, there are many other potential species yet to be considered for crop breeding for improving their nutritional and domestication traits [10].

Apart from modern breeding programs, the exploitation of conventional breeding techniques $[43,44]$ is also important for improving the traits as well as economic benefits of such underutilized species [43-50]. For instances, the traditional crop improvement techniques like mass selection, pure-line selection, pedigree method, bulk method, backcross method, single seed descent (SSD) method [43,49], mutation breeding [50] etc. are also essential for (i) improving the yield and quality attributing traits of the wild species, (ii) conferring resistance to biotic and abiotic stresses, (iii) enabling better adaptation by altering the crop duration, maturity/earliness etc., (iv) reducing the anti-nutritional factors, (v) enhancing the non-shattering characteristics, and (vi) improving the adaptation range as well as the photo and thermo sensitivity [43].

Targeted and participatory crop breeding programs [46,47] are necessary for some of the underutilized and neglected species such as Indian hemp (Crotalaria juncea), tarali (Melothria heterophylla), water leaf (Talinum fruticosum), Indian jute (Corchorus olitorius), Indian kudzu (Pueraria tuberosa), winter cherry (Physalis angulata), phalsa (Grewia asiatica), bur flower tree (Neolamarckia cadamba), wood apple (Aegle marmelos), jack bean (Canavalia ensiformis) etc. For this, a globally coordinated wild crop breeding program (including both conventional as well as modern breeding) under the leadership of CGIAR institutes and various national agricultural organizations is essential for improving the traits of potential lesser utilized species and to bring them to mainstream agriculture.

\section{Cultivating the Uncultivated: Third Step}

As opined by Massawe et al. (2016), neglected and underutilized wild species are a treasure trove for food security [51]. However, majority of such lesser known species are undomesticated, and therefore, farmers are not aware of their cultivation and propagation methods. Therefore, standardizing the agronomic practices (Figure 6) for such uncultivated edible crops is another major step for optimizing their resource use and also for improving the yield and nutritional quality [7]. 


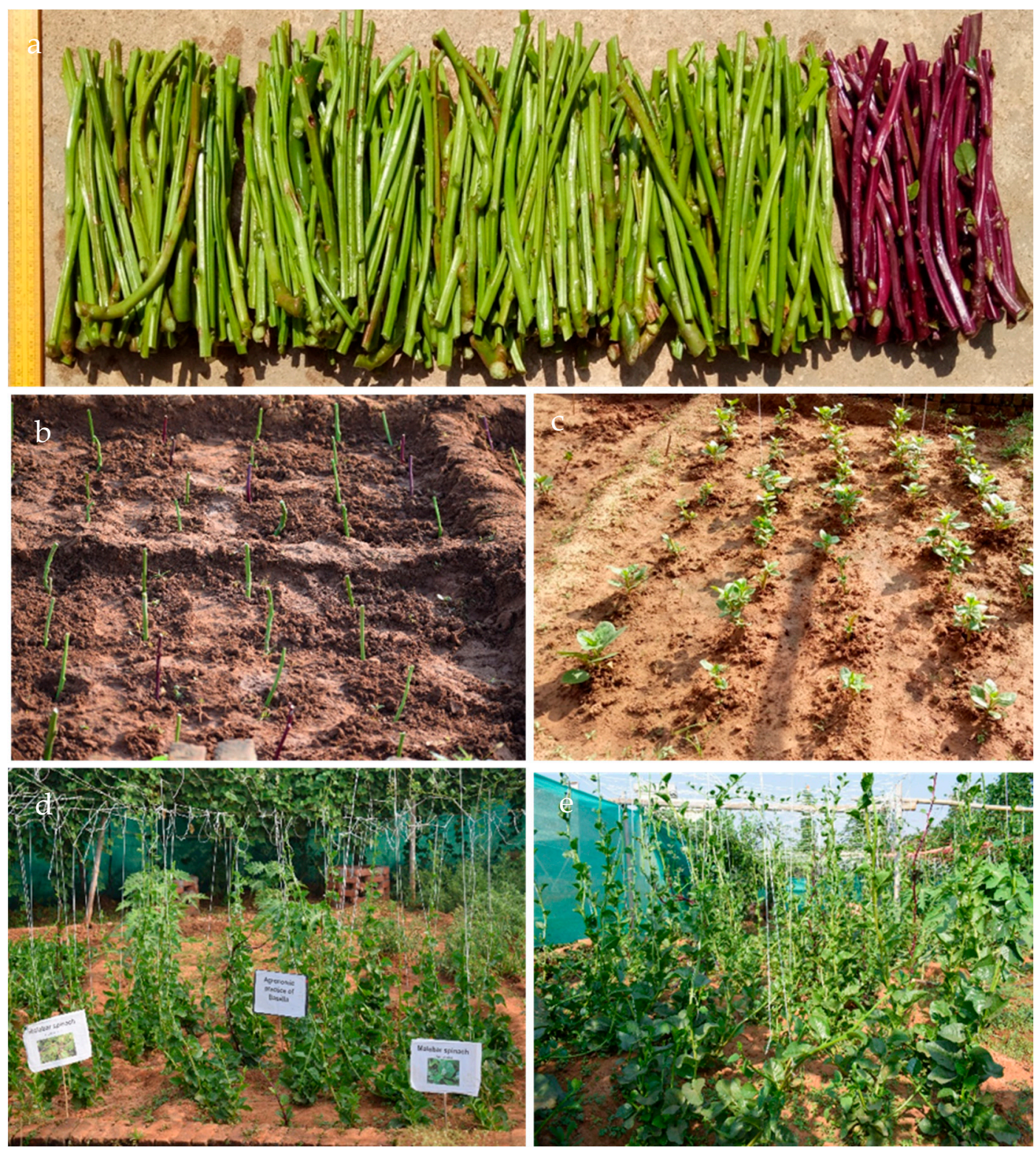

Figure 6. Optimization of agronomic practices and mass multiplication strategies are essential for the large-scale exploitation of underutilized crops. Photographs (a-e) shows the various stages of the mass propagation and cultivation of Indian spinach (Basella alba and Basella rubra).

Though the cultivation practices have been optimized for some of the wild species (for example, pigeon pea [40]; wild rocket [52]; terracrepolo [53]; Physalis sp. [54] etc.), such practices are yet to be standardized for a majority of the neglected species. For example, Basella alba and Basella rubra (Malabar spinach) are two of the highly nutritive, perennial leafy vegetable, capable of growing in diverse kind of habitat (including degraded and disturbed lands), there is no standardized protocols available for the large-scale cultivation of Basella sp. through stem cutting [11]. Similarly, there are many underutilized species yet to be introduced into farmers' fields (Figure 3A) and many optimial agronomic practices for improving their domestication traits. Moreover, the standardization of inventive agronomic practices is important for emission reduction [55] while increasing the soil's carbon pool [56,57].

Apart from validating the cultivation practices, standardization of suitable cropping models is also essential for successful crop diversification program. Since a majority of the wild crops are hardy and resilient to diverse climatic conditions, they can be used as border crops, as crop breaks, intercrops and also for multi-cropping and integrated farming practices [58]. Importantly, the cultivation of such wild 
crops will result in species diversification though multiple cropping and niche compartmentalization and thereby diversify the ecosystem functions and services [57]. Though monocropping system possess only limited traits to perform critical ecosystem functions (e.g., biological pest control, managing GHG emissions etc.), diversified cropping system have multiple traits to perform mosaic of functions (e.g., nutrient recycling, nitrogen fixation etc.) [56,59]. Moreover, crop diversification is also essential to ensure pollinator diversity such as honey bees, flies, beetles, moths, butterflies, wasps, ants, birds, and bats etc. as they are crucial for agrobiodiversity and other ecosystem services [60]. Therefore, internationally coordinated efforts are imperative to standardizing the cultivation practices of wild crops as well as for conducting their multi-locational trials in the various agro-climatic regions of the world, and such efforts must be linked to the concerned SDG targets of the appropriate national, regional, and international agencies for global sustainable development.

\section{Popularizing the Unpopular: Final Step}

Last, but not least, popularizing lesser known species as a climate resilient strategy for food security and resource conservation as well as promoting their role in maintaining ecosystem complexity to common people is another important step for their large-scale cultivation. For this, well-coordinated popularization efforts at various levels and scales are essential with the involvement of multiple stakeholders such as NGOs, State Governments, Local Help Groups, farming communities, National Science Academies, the FAO, CGIAR and other UN organizations. (Figures 7 and 8). Moreover, the standardization of cost-effective and suitable mass multiplication strategies (both micro and macro propagation) $[61,62]$ are important for reducing the cost of the plating materials and also for the large-scale popularization of such neglected and underutilized species because such mass multiplication strategies will make the cultivation of novel crops profitable to farmers.
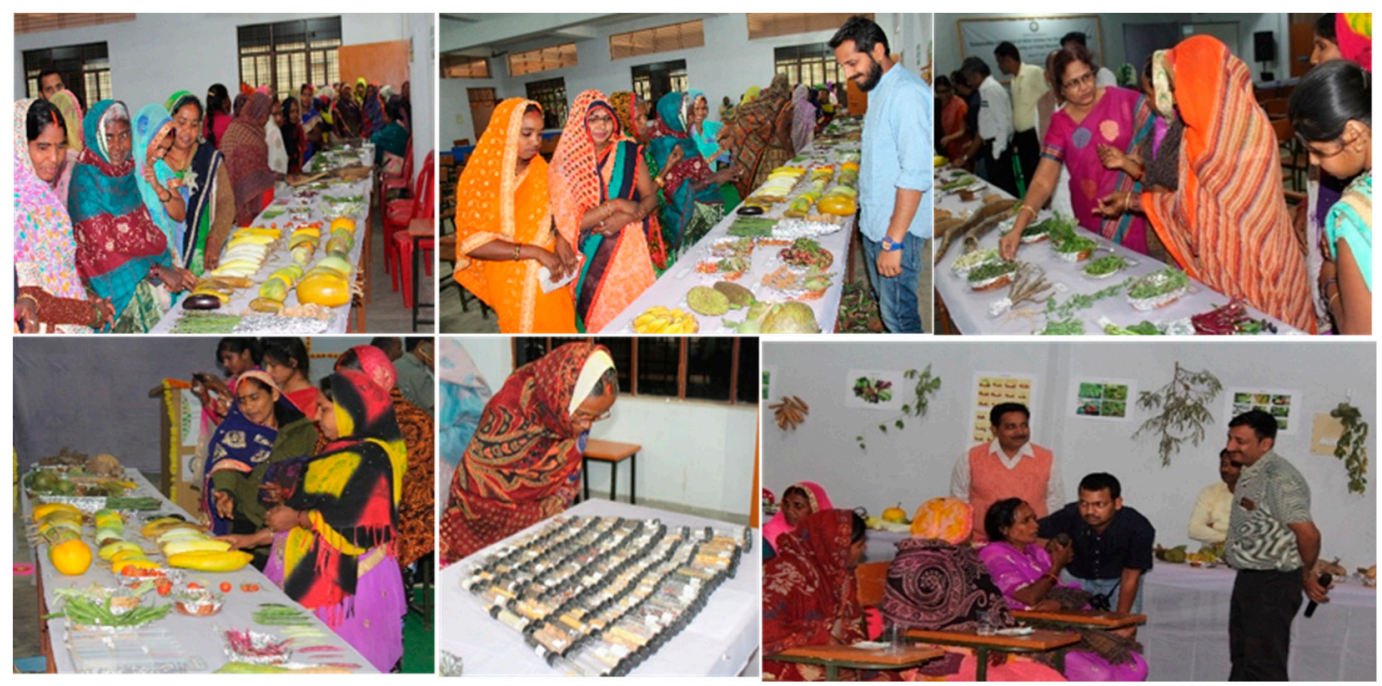

Figure 7. Popularization of neglected and wild edibles among diverse stakeholders especially women is important for dietary diversification program and thereby attaining food and nutritional security. Photographs shows the various interactive sessions of an awareness workshop on sustainable utilization of wild edibles for the health and well-being of the tribal women conducted by authors group in association with the National Academy of Sciences, India (NASI) and also with the support of Krishak, P.G College, Rajgarh, Mirzapur. 


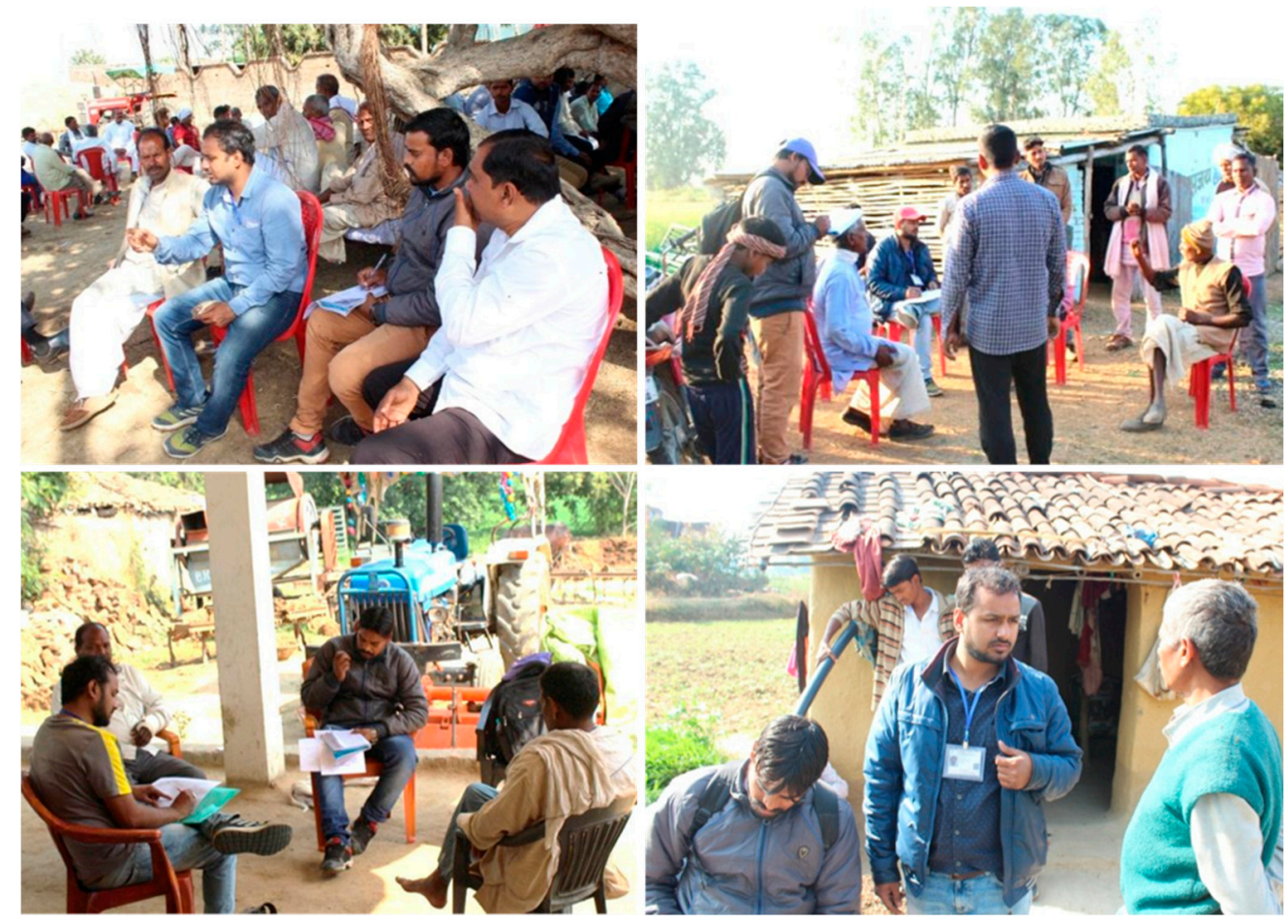

Figure 8. Periodic meetings and community involvements are essential for the awareness creation among indigenous and local community regarding the use of such neglected and underutilized crops for attaining global goals and also for encouraging them to use such species as an intermittent crop for intercropping and crop diversification in family and kitchen garden.

Harnessing indigenous and local knowledge and associated biocultural practices of the local people is an innovative strategy for conservation as well as popularization programs. Since the cultivation of such underutilized and neglected species will empower the indigenous community [5-7], suitable polices must be framed at the local and regional level to harness the ILK and biocultural practices of the local people for the exploration, large-scale exploitation, and also for developing the participatory crop improvement programs for the extensive utilization of such traditional and underutilized wild varieties for dietary diversification program. Therefore, conducting periodic awareness program for farmers especially women and other marginalized people is important for encouraging the introduction of various underutilized crops in their family and kitchen garden and also for developing suitable models for crop diversification based on such neglected and wild crops.

Developing a comprehensive, integrated and multi-utility database having the complete details of wild, neglected and underutilized crops in multiple languages (such as their origin, distribution, nutritional value, cultivation practices, crop genomics, crop improvement strategies, ecosystem services etc.) is of the utmost importance. Though there are websites and databases for crop wild relatives and wild crops, the content and coverage of them are limited. For example, the website of crop wild relatives only showcases 29 priority crops, listed in the Annex 1 of the International Treaty on Plant Genetic Resources for Food and Agriculture (ITPGRFA) (www.cwrdiversity.org) Similarly, the global distribution database of crop wild relatives published by the International Centre for Tropical Agriculture (CIAT) is another venture having the distribution database of crop gene pools of 80 species (www.gbif.org). The crop Wild Relatives Global Portal (www.cropwildrelatives.org) is another joint venture by Bioversity International, United Nations Environment Program (UNEP) and Global Environmental Facility (GEF). The International Legume Database and Information Services (ILDIS) is a promising database for legume species across the world (www.ildis.org). However, as we mentioned earlier, the species coverage in those databases must be expanded beyond the Annexure- 1 
of the ITPGRFA, and most promising species for global food security, especially from the lesser and underutilized leafy vegetables, wild tubers, wild fruits etc. must be included in the database.

The creation of a national or regional inventory of crop wild relatives is another promising strategy $[63,64]$. Cultivating wild crops in school gardens and using them for the mid-day meal programs of the developing countries, especially in South East Asia and Africa is another way for popularizing the lesser and under-utilized neglected species [17]. State governments can also play a vital role in encouraging the use of nutritionally rich wild crops. For example, the government of India has proposed nutritionally rich millets as 'nutrimillets' and urged for global solidarity in popularizing them by celebrating an international year for millets. As a result, the FAO council approves India's proposal to celebrate the year 2023 as the International Year of Millets (www.pib.nic.in). Furthermore, the existing 11 gene banks under CGIAR must also go beyond their proposed mandate (i.e., confined to the germplasm collection of a particular crop) and would start collecting germplasms of all uncollected species including wild leafy vegetables, wild vegetables, wild edible flowers, wild fruits, wild tubers etc. for ensuring the current and future food security.

\section{Concluding Remarks}

Unlocking the real potential of undomesticated and wild crops is imperative for global food and nutritional security and also for attaining many other UN-SDGs. However, targeted crop improvement, domestication as well as cost-effective mass cultivation programs are essential for exploiting their real potential. Therefore, international collaborations under the joint leaderships of FAO and CGIAR institutions, national agriculture institutions and State Governments are essential for the exploration, popularization, as well as the large-scale exploitation of undomesticated crops for ensuring the food and nutritional demand of the global population, and also for communicating their multipurpose benefits to various stakeholders, and framing suitable policies accordingly.

Author Contributions: Conceptualization, P.C.A.; initial draft, A.S. and P.C.A; revision, A.S., P.K.D., R.C., R.K.D., K.K.P., G.S.S., P.C.A.; editing, P.C.A., final approval, A.S., P.K.D., R.C., R.K.D., K.K.P., G.S.S., P.C.A.; supervision, P.C.A., co-supervision, G.S.S.

Funding: Authors have not received any specific funding for this work.

Acknowledgments: Authors are grateful to Head, DESD and Director, IESD for support and encouragement. A.S. is thankful to Jawaharlal Nehru Trust for Jawaharlal Nehru Scholarship; P.K.D. is thankful to UGC for Senior Research Fellowship; R.C. is grateful to CSIR for Junior Research Fellowship. We have the support of Nitin, Gangesh Kumar, Sujeet Bharati, Amit Bundela, and Avinash Kushwaha for field exploration. Thanks, are also due to Principal and Managers of Krishak PG College for their whole-hearted support for this study. Special thanks go to Paras Nath Singh for his kind help and support for this research study. Mahadav Karki, Vice-Chair, IUCN-CEM and Angela Andrade, Chair, IUCN-CEM for encouragements.

Conflicts of Interest: The authors declare no conflict of interest.

\section{References}

1. Godfray, H.C. Food security: The challenge of feeding 9 billion people. Science 2010, 327, 812-818. [CrossRef] [PubMed]

2. Rockstrom, J.; Steffen, W.; Noone, K.; Persson, A.; Chapin, F.S., III; Lambin, E.F.; Lenton, T.M.; Scheffer, M.; Folke, C.; Schellnhuber, H.J.; et al. A safe operating space for humanity. Nature 2009, 461, 472-475. [CrossRef] [PubMed]

3. Dubey, P.K.; Singh, G.S.; Abhilash, P.C. Agriculture in a changing climate. J. Clean. Prod. 2016, 113, $1046-1047$. [CrossRef]

4. Tripathi, V.; Edrisi, S.A.; Chen, B.; Vilu, R.; Gathergood, N.; Abhilash, P.C. Biotechnological advances for restoring degraded lands for sustainable development. Trends Biotechnol. 2017, 35, 847-859. [CrossRef] [PubMed]

5. Parodi, A.; Leip, A.; De Boer, I.J.M.; Slegers, P.M.; Ziegler, F.; Temme, E.H.; Herrero, M.; Tuomisto, H.; Valin, H.; Van Middelaar, C.E.; et al. The potential of future foods for sustainable and healthy diets. Nat. Sustain. 2018, 1, 782. [CrossRef] 
6. Nair, K.P. Chapter Four-Utilizing Crop Wild Relatives to Combat Global Warming. Adv. Agron. 2019, 153, 175-258.

7. Ewel, J.J.; Schreeg, L.A.; Sinclair, T.R. Resources for Crop Production: Accessing the Unavailable. Trends Plant Sci. 2018, 24, 121-129. [CrossRef] [PubMed]

8. Singh, A.; Abhilash, P.C. Agricultural Biodiversity for Sustainable Food Production. J. Clean. Prod. 2018, 172, 1368-1369. [CrossRef]

9. Gruber, K. The living library. Nature 2017, 544, S8-S10. [CrossRef]

10. Singh, A.; Dubey, P.K.; Abhilash, P.C. Food for thought: Putting wild edibles back on the table for combating hidden hunger in developing countries. Curr. Sci. 2018, 115, 611-613. [CrossRef]

11. Singh, A.; Dubey, P.K.; Chaurasiya, R.; Mathur, N.; Kumar, G.; Bharati, S.; Abhilash, P.C. Indian spinach: An underutilized perennial leafy vegetable for nutritional security in developing world. Energy Ecol. Environ. 2018, 3, 195-205. [CrossRef]

12. Padulosi, S.; Thompson, J.; Rudebjer, P. Fighting Poverty, Hunger and Malnutrition with Neglected and Underutilized Species (NUS): Needs, Challenges and the Way Forward; Bioversity International: Rome, Italy, 2013.

13. Singh, A.; Abhilash, P.C. Varietal dataset of nutritionally important Lablab purpureus (L.) sweet from Eastern Uttar Pradesh, India. Data Brief 2019, 24, 103935. [CrossRef] [PubMed]

14. Singh, A.; Singh, G.S.; El-Keblawy, A.; Abhilash, P.C. Neglected and Underutilized Crops: Towards UN-Sustainable Development Goals. In Springer Brief in Environmental Sciences; 2019; in press.

15. Kew, R.B.G. The State of the World's Plants Report; Royal Botanic Gardens: Kew, London, UK, 2016.

16. Arora, A.K. Diversity in Underutilized Plant Species-An Asia Pacific Perspectives; Bioversity International: New Delhi, India, 2014; 203p.

17. FAO. Future Smart Food; Unlocking Hidden Treasures in Asia and the Pacific; Regional Initiative on Zero Hunger Challenge Policy Brief Agricultural Diversification for a Healthy Diet; Food and Agricultural Organization: Rome, Italy, 2017; Available online: http://www.fao.org/3/a-i7717e.pdf (accessed on 10 May 2019).

18. Varshney, R.K.; Ribaut, J.-M.; Buckler, E.S.; Tuberosa, R.; Rafalski, J.A.; Langridge, P. Can genomics boost productivity of orphan crops? Nat. Biotechnol. 2012, 30, 1172. [CrossRef] [PubMed]

19. Leng, P.F.; Lübberstedt, T.; Xu, M.L. Genomics-assisted breeding-A revolutionary strategy for crop improvement. J. Integr. Agric. 2017, 16, 2674-2685. [CrossRef]

20. Jiao, Y.; Zhao, H.; Ren, L.; Song, W.; Zeng, B.; Guo, J.; Wang, B.; Liu, Z.; Chen, J.; Li, W.; et al. Genome-wide genetic changes during modern breeding of maize. Nat. Genet. 2012, 44, 812-815. [CrossRef] [PubMed]

21. Li, J.Y.; Wang, J.; Zeigler, R.S. The 3,000 rice genomes project: New opportunities and challenges for future rice research. GigaScience 2014, 3, 8. [CrossRef] [PubMed]

22. De Leeuw, M.; Martinant, J.P.; Duborjal, H.; Laffaire, J.B.; Beugnot, R. High throughput SNP discovery in wheat using methylation-sensitive digestion and next-generation sequencing. In Proceedings of the 19th International Triticeae Mapping Initiative Meeting, Clermont-Ferrand, France, 31 August-4 September 2009; INRA (Institut National de la Recherche Agronomique): Paris, France, 2009.

23. Takahagi, K.; Yamaguchi, Y.U.; Yoshida, T.; Sakurai, T.; Shinozaki, K.; Mochida, K.; Saisho, D. Analysis of single nucleotide polymorphisms based on RNA sequencing data of diverse bio-geographical accessions in barley. Sci. Rep. 2016, 6, 33199. [CrossRef]

24. Valliyodan, B.; Ye, H.; Song, L.; Murphy, M.; Shannon, J.G.; Nguyen, H.T. Genetic diversity and genomic strategies for improving drought and waterlogging tolerance in soybeans. J. Exp. Bot. 2016, 68, 1835-1849. [CrossRef]

25. Yang, H.; Jian, J.; Li, X.; Renshaw, D.; Clements, J.; Sweetingham, M.W.; Li, C. Application of whole genome re-sequencing data in the development of diagnostic DNA markers tightly linked to a disease-resistance locus for marker-assisted selection in lupin (Lupinus angustifolius). BMC Genom. 2015, 16, 660. [CrossRef]

26. Liu, Q.; Liu, J.; Zhang, P.; He, S. Root and tuber crops. In Encyclopaedia of Agriculture and Food Systems; Elsevier: London, UK, 2014; pp. 46-61.

27. Harouna, D.V.; Venkataramana, P.B.; Ndakidemi, P.A.; Matemu, A.O. Under-exploited wild Vigna species potentials in human and animal nutrition: A review. Glob. Food. Secur. 2018, 18,1-11. [CrossRef]

28. Pimienta-Barrios, E. Prickly pear (Opuntia spp.): A valuable fruit crop for the semi-arid lands of Mexico. J. Arid. Environ. 1994, 28, 1-11. [CrossRef] 
29. Greene, S.L.; Hart, T.C.; Afonin, A. Using geographic information to acquire wild crop germplasm for ex situ collections: II. Post-collection analysis. Crop Sci. 1999, 39, 843-849. [CrossRef]

30. Broegaard, R.B.; Rasmussen, L.V.; Dawson, N.; Mertz, O.; Vongvisouk, T.; Grogan, K. Wild food collection and nutrition under commercial agriculture expansion in agriculture-forest landscapes. For. Policy Econ. 2017, 84, 92-101. [CrossRef]

31. Reynolds, M.P.; Quilligan, E.; Aggarwal, P.K.; Bansal, K.C.; Cavalieri, A.J.; Chapman, S.C.; Chapotin, S.M.; Datta, S.K.; Duveiller, E.; Gill, K.S.; et al. An integrated approach to maintaining cereal productivity under climate change. Glob. Food Secur. 2016, 8, 9-18. [CrossRef]

32. Rasheed, A.; Hao, Y.; Xia, X.; Khan, A.; Xu, Y.; Varshney, R.K.; He, Z. Crop Breeding chips and genotyping platforms: Progress, challenges, and perspectives. Mol. Plant 2017, 10, 1047-1064. [CrossRef] [PubMed]

33. Varshney, R.K.; Bansal, K.C.; Aggarwal, P.K.; Datta, S.K.; Craufurd, P.Q. Agricultural biotechnology for crop improvement in a variable climate: Hope or hype? Trends Plant Sci. 2011, 16, 363-371. [CrossRef] [PubMed]

34. Huang, S.; Weigel, D.; Beachy, N.R.; Li, J. A proposed regulatory framework for genome-edited crops. Nat. Genet. 2016, 48, 109-111. [CrossRef] [PubMed]

35. Østerberg, J.T.; Xiang, W.; Olsen, L.I.; Edenbrandt, A.K.; Vedel, S.E.; Christiansen, A.; Landes, X.; Andersen, M.M.; Pagh, P.; Sandøe, P.; et al. Accelerating the domestication of new crops: Feasibility and approaches. Trends Plant Sci. 2017, 22, 373-384. [CrossRef] [PubMed]

36. Lemmon, Z.H.; Reem, N.T.; Dalrymple, J.; Soyk, S.; Swartwood, K.E.; Rodriguez-Leal, D.; Van Eck, J.; Lippman, Z.B. Rapid improvement of domestication traits in an orphan crop by genome editing. Nat. Plants 2018, 4, 766. [CrossRef]

37. D'Amelia, V.; Villano, C.; Aversano, R. Emerging Genetic Technologies to Improve Crop Productivity. Encycl. Food Secur. Sustain. 2019, 3, 152-158.

38. Xu, J.; Hou, Q.M.; Khare, T.; Verma, S.K.; Kumar, V. Exploring miRNAs for developing climate-resilient crops: A perspective review. Sci. Total Environ. 2019, 653, 91-104. [CrossRef] [PubMed]

39. Khan, M.Z.; Zaidi, S.S.A.; Amin, I.; Mansoor, S. A CRISPR way for fast-forward crop domestication. Trends Plant Sci. 2019, 24, 293-296. [CrossRef] [PubMed]

40. Khoury, C.K.; Castanñeda-Alvarez, N.P.; Achicanoy, H.A.; Sosa, C.C.; Bernau, V.; Kassa, M.T.; Norton, S.L.; van der Maesen, L.J.S.; Upadhyaya, H.D.; Ramiírez-Villegas, J.; et al. Crop wild relatives of pigeon pea [Cajanus cajan (L.) Millsp.]: Distributions, ex situ conservation status, and potential genetic resources for abiotic stress tolerance. Biol. Conserv. 2015, 184, 259-270. [CrossRef]

41. Muthamilarasan, M.; Dhaka, A.; Yadav, R.; Prasad, M. Exploration of millet models for developing nutrient rich graminaceous crops. Plant Sci. 2016, 242, 89-97. [CrossRef] [PubMed]

42. Singh, V.; Goel, R.; Pande, V.; Asif, M.H.; Mohanty, C.S. De novo sequencing and comparative analysis of leaf transcriptomes of diverse condensed tannin-containing lines of underutilized Psophocarpus tetragonolobus (L.) DC. Sci. Rep. 2017, 7, 44733. [CrossRef]

43. Rakshit, S.; Bellundagi, A. Chapter 5-Conventional breeding techniques in Sorghum. In Breeding Sorghum for Diverse End Uses; Woodhead Publishing: Duxford, UK, 2019. [CrossRef]

44. Weltzein, E.; Christinck, A. Chapter 8-Participatory breeding: Developing improved and relevant crop varieties with farmers. In Agricultural Systems; Elsevier: London, UK, 2017; pp. 259-301. [CrossRef]

45. Balázs, E.; Divéki, Z. Boosting super-domestication: From crop domestication to genome editing. S. Afr. J. Bot. 2019. [CrossRef]

46. Waldman, K.B.; Kerr, J.M.; Isaacs, K.B. Combining participatory crop trials and experimental auctions to estimate farmer preferences for improved common bean in Rwanda. Food Policy 2014, 46, 183-192. [CrossRef]

47. Annicchiarico, P.; Russi, L.; Romani, M.; Pecetti, L.; Nazzicari, N. Farmer-participatroy vs. conventional market-oriented breeding of inbred crops using phenotypic and genome-enabled approaches: A pea case study. Field Crops Res. 2019, 232, 30-39. [CrossRef]

48. Allard, R.W. Principles of Plant Breeding; John Wiley and Sons Inc.: New York, NY, USA, 1960.

49. Rakshit, S.; Gomashe, S. Basics of plant breeding with reference to sorghum. In Basics of Sorghum Breeding and AICSIP Data Management; Rakshit, S., Patil, J.V., Eds.; Directorate of Sorghum Research: Hyderabad, India, 2013; pp. 9-16.

50. Soeranto, H.; Trikoesoemaningtyas, T.; Sihono, S.; Sungkono, S. Development of sorghum tolerant to acid soil using induced mutation with gamma irradiation. At. Indones. 2010, 36, 11-15. 
51. Massawe, F.; Mayes, S.; Cheng, M. Crop diversity: An unexploited treasure trove for food security. Trends Plant Sci. 2016, 5, 365-368. [CrossRef]

52. Schiattone, M.I.; Candido, V.; Cantore, V.; Montesano, F.F.; Boari, F. Water use and crop performance of two wild rocket genotypes under salinity conditions. Agric. Water Manag. 2017, 194, 214-221. [CrossRef]

53. Maggini, R.; Benvenuti, S.; Leoni, F.; Pardossi, A. Terracrepolo (Reichardia picroides (L.) Roth.): Wild food or new horticultural crop? Sci. Hortic. 2018, 20, 224-231. [CrossRef]

54. Saavedra, J.C.M.; Zaragoza, F.A.R.; Toledo, D.C.; Hernández, C.V.S.; Vargas-Ponce, O. Agromorphological characterization of wild and weedy populations of Physalis angulata in Mexico. Sci. Hortic. 2019, 246, 86-94. [CrossRef]

55. Wollenberg, E.; Richards, M.; Smith, P.; Havlik, P.; Obersteiner, M.; Tubiello, F.N.; Herold, M.; Gerber, P.; Carter, S.; Reisinger, A.; et al. Reducing emissions from agriculture to meet the $2{ }^{\circ} \mathrm{C}$ Target. Glob. Chang. Biol. 2016, 22, 3859-3864. [CrossRef] [PubMed]

56. Power, A.G. Ecosystem services and agriculture: Trade-offs and synergies. Phils. Trans. R. Soc. B 2010, 365, 2959-2971. [CrossRef]

57. Poppy, G.M.; Chiotha, S.; Eigenbrod, F.; Harvey, C.A.; Honzak, M.; Hudson, M.D.; Jarvis, A.; Madise, N.J.; Schreckenberg, K.; Shackleton, C.M.; et al. Food security in a perfect storm: Using the ecosystem services framework to increase understanding. Phils. Trans. R. Soc. Lond. B 2014, 369, 20120288. [CrossRef]

58. Dubey, P.K.; Singh, G.S.; Abhilash, P.C. Adaptive agricultural practices: Building resilience in a changing climate. In SpringerBriefs in Environmental Science; Springer: New York, NY, USA, 2019; ISBN 978-3-030-15518-6. [CrossRef]

59. Dubey, R.K.; Tripathi, V.; Dubey, P.K.; Singh, H.B.; Abhilash, P.C. Exploring rhizospheric interactions for agricultural sustainability: The need of integrative research on multi-trophic interactions. J. Clean. Prod. 2016, 115, 362-365. [CrossRef]

60. Potts, S.G.; Imperatriz-Fonseca, V.; Ngo, H.T.; Aizen, M.A.; Biesmeijer, J.C.; Breeze, T.D.; Dicks, L.V.; Garibaldi, L.A.; Hill, R.; Settele, J.; et al. Safeguarding pollinators and their values to human well-being. Nature 2016, 540, 220-229. [CrossRef]

61. ul-Haq, Z.; Rashid, A.; Khan, S.M.; Razzaq, A.; Al-Yahyai, R.A.; Kamran, S.; Ali, S.G.; Ali, S.; Saifullah; Abdullah; et al. In vitro and in vivo propagation of Monotheca buxifolia (Falc.) A. DC. An economical medicinal plant. Acta Ecol. Sin. 2019, in press. [CrossRef]

62. Jalali, N.; Naderi, R.; Shahi-Gharahlar, A.; da Silva, J.A.T. Tissue culture of Cyclamen spp. Sci. Hortic. 2012, 137, 11-19. [CrossRef]

63. Maxted, N.; Scholten, M.; Codd, R.; Ford-Lloyd, B. Creation and use of a national inventory of crop wild relatives. Biol. Conserv. 2007, 140, 142-159. [CrossRef]

64. Khoury, C.K.; Amariles, D.; Soto, J.S.; Victoria Diaz, M.; Sotelo, S.; Sosa, C.C.; Ramírez-Villegas, J.; Achicanoy, H.A.; Velásquez-Tibatá, J.; Guarino, L.; et al. Comprehensiveness of conservation of useful wild plants: An operational indicator for biodiversity and sustainable development targets. Ecol. Indic. 2019, 98, 420-429. [CrossRef]

(C) 2019 by the authors. Licensee MDPI, Basel, Switzerland. This article is an open access article distributed under the terms and conditions of the Creative Commons Attribution (CC BY) license (http://creativecommons.org/licenses/by/4.0/). 